Tropical Journal of Pharmaceutical Research September 2014; 13 (9): 1561-1566

ISSN: $1596-5996$ (print); 1596-9827 (electronic)

(c) Pharmacotherapy Group, Faculty of Pharmacy, University of Benin, Benin City, 300001 Nigeria.

All rights reserved.

Available online at http://www.tjpr.org

Review Article

http://dx.doi.org/10.4314/tjpr.v13i9.26

\title{
Pharmacological Applications of Quercetin and its Derivatives: A Short Review
}

\author{
Aneela Maalik ${ }^{1 \star}$, Farhan A. Khan ${ }^{1}$, Amara Mumtaz ${ }^{1}$, Adeem Mehmood ${ }^{1}$, Saira \\ Azhar $^{2}$, Muhammad Atif ${ }^{1}$, Sabiha Karim ${ }^{3}$, Yasir Altaf ${ }^{1}$ and Imran Tariq ${ }^{3}$ \\ 1Department of Chemistry, 2Department of Pharmacy, COMSATS Institute of Information Technology, Abbottabad-22060, \\ KPK, 3University College of Pharmacy, University of Punjab, Lahore, Pakistan
}

*For correspondence: Email: aneelamaalik@ciit.net.pk; Tel: +92 333549 0834; Fax: +92 992383441

Revised accepted: 7 August 2014

\begin{abstract}
Quercetin (3,3',4',5,7-pentahydroxyl-flavone) is a flavonol, and it belongs to a class of plant secondary metabolites known as flavonoids. It is present in man's daily diet and is known for biological activities such as antioxidant, antiviral, anticancer, antimicrobial, anti-inflammatory and many more. Quercetin has been reported for its antioxidant and antiviral applications, hence, it is not only used as such but also its various derivatized forms have potentials for development into drugs for the treatment of diseases caused by oxidative stress and lethal viruses.
\end{abstract}

Keywords: Quercetin, Antioxidant, Pharmacological, Anticancer, Antimicrobial, Antiviral, Hepatoprotective

Tropical Journal of Pharmaceutical Research is indexed by Science Citation Index (SciSearch), Scopus, International Pharmaceutical Abstract, Chemical Abstracts, Embase, Index Copernicus, EBSCO, African Index Medicus, JournalSeek, Journal Citation Reports/Science Edition, Directory of Open Access Journals (DOAJ), African Journal Online, Bioline International, Open-J-Gate and Pharmacy Abstracts

\section{INTRODUCTION}

Quercetin is a plant pigment, abundantly occurs in many ethnic plants, especially onion and tea, therefore, a sufficient amount may be consumed daily [1]. Quercetin has importance in terms of ethnopharmacology such as its use as antioxidant, anticancer and neuroprotective [2]. It has been reported as an efficient free radical scavenger (antioxidant) [3]. In clinical trials (phase-I), quercetin has been reported to exhibit inhibitory effect on tyrosine kinase which suggests that it has antitumor therapeutic potentials [4].

The review has been prepared using databases such as ISI Web of Knowledge, Science Direct, and Google Scholar, and covers the literature from the last decade. This article includes only original research articles published in English language; articles published in other languages are excluded.

\section{PHARMACOLOGICAL IMPORTANCE OF QUERCETIN}

Quercetin is a versatile molecule (Figure 1) with many pharmacological properties including antioxidant, neurological, antiviral, anticancer, cardiovascular, antimicrobial, anti-inflammatory, hepatoprotective, protective of the reproductive system and anti-obesity agent. The literature available on these properties has been summarized here in this review (Table 1). 
<smiles>O=c1c(O)c(-c2ccc(O)c(O)c2)oc2cc(O[C@@H]3O[C@H](O)[C@@H](O)[C@H](O)[C@H]3O)cc(O)c12</smiles>

Quercetin 7-O-Rhamnoside<smiles>C=C(O)[C@H]1O[C@@H](Oc2c(-c3ccc(O)c(O)c3)oc3cc(O)cc(O)c3c2=O)[C@H](O)[C@@H](O)[C@H]1O</smiles>

Quercetin 3-O-D-glucuronide<smiles>O=c1c(O)c(-c2ccc(O)c(O)c2)oc2cc(O)cc(O)c12</smiles>

Quercetin<smiles>COc1cc(OC)c2c(=O)c(OC)c(-c3ccc(OC)c(OC)c3)oc2c1</smiles>

Quercetin pentamethylether<smiles>COc1ccc(-c2oc3cc(O)cc(O)c3c(=O)c2O)cc1O</smiles>

Quercetin 4'-methylether

Figure 1: Quercetin and some of its derivatives

Table 1: Pharmacological properties of quercetin

\begin{tabular}{ll}
\hline $\begin{array}{l}\text { Pharmacological } \\
\text { property }\end{array}$ & References \\
\hline Antioxidant activity & {$[4],[5],[6],[7],[8],[9]$,} \\
& {$[10],[11]$} \\
Neurological effects & {$[12],[13],[14],[15]$} \\
Antiviral activity & {$[16],[17],[18],[19],[20]$,} \\
& {$[21],[22]$} \\
Anticancer activity & {$[2],[23],[24],[25],[26]$} \\
Cardiovascular protection & {$[4],[27],[28],[29],[30]$} \\
Antimicrobial activity & {$[31],[32],[33]$} \\
Anti-inflammatory activity & {$[34],[35],[36],[37],[38]$,} \\
& {$[39]$} \\
Hepatoprotective activity & {$[40],[41],[42]$} \\
\hline
\end{tabular}

\section{Antioxidant activity}

Quercetin is capable of scavenging reactive oxygen species and its antioxidant potential is attributed to this free radical scavenging activity [5]. During in vitro studies antioxidant behavior makes quercetin capable of inhibiting cataract formation caused by oxidative stress in rat eye lens cultured in a hydrogen peroxide environment [6]. Recently, in vivo study, it has been reported that oxidative damage caused by an industrial compound $\mathrm{CCl}_{4}$ can be effectively reduced using methanolic extract of Heterotheca inuloides containing quercetin [7]. Moreover, quercetin has also been reported to show in vivo inhibitory effect against tert-butylhydroperoxide induced lipid peroxidation in human sperm cells [8]. In another study, quercetin at a dose of 25-50 $\mathrm{mg} / \mathrm{kg}$ reported to show antioxidant behavior against the oxidative stress caused by streptozotocin-induced diabetes mellitus in rats [9]. Moreover, quercetin has also been reported as an efficient antioxidant and stabilizer in polyethylene with a dosage of $250 \mathrm{ppm}$ an increase was described in the long term residual stability of the polymer [10]. Furthermore, quercetin-cadmium complexes has also been reported to have higher stability constant $(K f)$ value, therefore, quercetin is proposed to be used as chelating agent in the chelation therapy treatment for the removal of toxic metal ions [11]. 


\section{Neurological effects}

Quercetin is neuroprotective as well as neurotoxic. Therefore, it has been reported to behave as a neuroprotector in rat brain when used in combination to fish oil [12]. Quercetin has been reported to show beneficial effects against neurodegenerative diseases (example, Alzheimer's disease) where it shows inhibitory effect against acetylcholinesterase [13]. Moreover, quercetin has been reported to reduce the oxidative stress induced by 6hydroxydopamine in neurons from the brain striatum of rats [14]. A study on healthy P19 neurons reported that quercetin treatment did not affect neuron survival but a depletion in intracellular glutathione contents has been observed which can affect working of nervous system [15]. However, prolonged use of antioxidant supplements is safe for human health is still a big question. .

\section{Antiviral activity}

Viral diseases are a growing threat for human health. Quercetin has also been found affective against a variety of viruses. In a study, quercetin has been reported potent against budding in MT2 cells caused by human T-lymphotropic virus 1 [16]. Moreover, a low antiviral activity of quercetin with $\mathrm{IC}_{50}=212.1 \mu \mathrm{g} / \mathrm{mL}$ was reported against anti-Japanese encephalitis virus (JEV) which is responsible for mosquito-borne disease known as Japanese encephalitis [17]. However, quercetin has been reported for profound antiviral effect against dengue virus type-2 [18]. Quercetin enriched lecithin formulations, are reported to show antiviral activity in vitro using African green monkey's Vero cells [19]. Furthermore, quercetin has been reported to suppress the hepatitis $\mathrm{C}$ virus by inhibiting nonstructural protein 3 protease activity [20]. Quercetin-3-O- $\beta$-D-glucuronide, during in vivo studies has been reported to be effective against influenza-A virus [21] and quercetin 7rhamnoside was found effective against porcine epidemic diarrhea virus [22].

\section{Anticancer activity}

Cancer has been found in sixty different parts of the human body and currently requires new therapeutics for its treatment. Quercetin has been reported as a potent anticancer agent during in vitro studies in various cancer cell lines and in vivo studies in rodents especially mice [2]. Quercetin has radical scavenging potential, therefore, it is capable of preventing cancer induced by oxidative stress [23]. The chemoprotective action of quercetin through apoptosis and metastasis against tumor cell lines makes it a strong candidate as a potential anticancer agent [24]. Moreover, quercetin in combination with intratumoral doxorubicin injection has been reported to result in enhancing immune responses against growth in breast tumors [25]. However, during in vitro study using human MCF-7 cells (Michigan Cancer Foundation-7), quercetin has been reported to inhibit angiogenesis in tamoxifen-resistant cancer in breast cells [26].

\section{Cardiovascular protection}

Quercetin has been reported to play a role in reducing cardiovascular diseases and this property is attributed to its anti-inflammatory nature [27]. During an in vitro study on isolated rat arteries, quercetin in its a-glycan form has been demonstrated to be a vasodilator [28]. Epidemiological data show a positive correlation between a diet rich in quercetin and reduction in cardiovascular problems [4]. However, quercetin has also been reported for a reduction in cardiovascular endangering factors including fibrinogen and human C-reactive protein in human transgenic mice [29]. Moreover, in vivo study in mice reported that due to its antiinflammatory effect quercetin is also capable of preventing calcium chloride induced abdominal aortic aneurism [30].

\section{Antimicrobial activity}

Quercetin being antimicrobial agent plays its role in meat of fattening lambs which have been supplemented by quercetin diet, a decrease in microbial growth has been reported upon freezing [31]. Additionally, chitosan functioned by quercetin in the presence of Lucas has a remarkable antimicrobial activity against bacterial species such as Escherichia coli, Salmonellae enterica and Listeria monocytogenes [32]. Moreover, quercetin also act as bacteriostatic due to its capacity to inhibit D-Ala-D-Ala ligation in bacterial cells, by inhibiting D-alanine: Dalanine ligase enzyme and preventing the bacterial growth [33]. Currently, bacteria are getting resistant against the available antibacterial drugs therefore; more advanced and effective drugs are required to counter these resistant bacteria. Quercetin being bacteriostatic is a good molecule for antibacterial drug research.

\section{Antiinflammatory activity}

Quercetin is known for anti-inflammatory effects, during in vivo study, it has been reported that orally administered quercetin mixed with 
polysorbate 80 inhibited paw edema in rats [34]. Quercetin and its glycoside derivatives, due to their lower absorption through the skin surface were reported ineffective against topical inflammation, however, a pentamethylether derivative of quercetin has excellent absorption properties through skin route in rat and is reported as anti-inflammatory agent [35]. Furthermore, quercetin applied on a cultured hepatocyte cell line has been reported to show an inhibitory effect against inflammatory causing agents like reactive C-protein and nitric oxide synthase [36]. However, in vivo study in mice has been reported to show a reduction in expression of inflammatory genes by using quercetin enriched diet [37]. An improvement in insulin sensitivity has been reported by intraperitoneal administration of quercetin in mice, subsequently a reduction in inflammation was reported which is attributed to the insulin resistance [38]. However, during in vivo and ex vivo studies performed in healthy human volunteers administered with quercetin reported no effect on inflammatory agents present in human blood [39]. Beneficial effects of quercetin and its derivatives against inflammation, in vivo models suggest that it is a potent anti-inflammatory agent.

\section{Hepatoprotective activity}

In vivo study in non-alcoholic steatohepatitis gerbils, it has been reported that gerbils which had been orally administered with quercetin showed a decreased deposition of fats in liver cells, thereby protecting liver cells from fibrosis [40]. Moreover, in vivo study in mice relating to the hepatoprotective mechanism of quercetin reported that it is the hemeoxygenase 1 that triggers the function of quercetin against induced hepatotoxicity; hepatoprotectivity was then observed by the decrease in plasma concentration of alanine aminotransferase [41]. Oxidative damage induced by ethanol in rat hepatocytes has been reported to be curable with the quercetin administration [42]. Hepatoprotectivity of quercetin suggests that its administration may be helpful to prevent liver damage, thus quercetin may be a suitable natural product as hepatoprotective agent.

Along with above mentioned pharmacological activities, quercetin has also been reported for its protective effect on the reproductive system of embryonic chicken and induced toxicity by quinine sulfate in rats $[43,44]$. Literature also reveals anti-obesity use of quercetin [45].

\section{CONCLUSION}

Quercetin and its derivatives have been studied for their pharmacological properties in the recent years. We have discussed some of the pharmacological properties, including, antiviral, antioxidant, anticancer, antimicrobial, antiinflammatory, neurological effects, cardiovascular, and hepatoprotective. However, research published on anti-inflammatory aspect of quercetin and its derivatives is not enough for its application in humans. Quercetin and its derivatives are versatile molecules and should be investigated more extensively for their wider applications in human health, including their therapeutic activities.

\section{ACKNOWLEDGEMENT}

We apologise to all our colleagues whose valuable work could not be cited and cordially acknowledge Higher Education Commission (HEC) for providing research facilities.

\section{REFERENCES}

1. Manach $C$, Williamson $G$, Morand $C$, Scalbert A,Remesy C. Bioavailability and bioefficacy of polyphenols in humans. I. Review of 97 bioavailability studies. Am J Clin Nutrit 2005; 81: 230S-242S.

2. Dajas F. Life or death: Neuroprotective and anticancer effects of quercetin. J Ethnopharmacol 2012; 143: 383-396.

3. Ferry DR, Smith A, Malkhandi J, Fyfe DW, Detakats PG, Anderson D, Baker J,Kerr DJ. Phase I clinical trial of the flavonoid quercetin: pharmacokinetics and evidence for in vivo tyrosine kinase inhibition. Clin Cancer Res 1996; 2: 659-668.

4. Jan AT, Kamli MR, Murtaza I, Singh JB, Ali A,Haq QMR. Dietary Flavonoid Quercetin and Associated Health Benefits An Overview. Food Rev Int 2010; 26: 302317.

5. Boots AW, Haenen GR,Bast A. Health effects of quercetin: from antioxidant to nutraceutical. Eur J Pharmacol 2008; 585: 325-337.

6. Stefek, M,Karasu C. Eye lens in aging and diabetes: effect of quercetin. Rejuvenation Res 2011; 14: 525534.

7. Coballase-Urrutia E, Pedraza-Chaverri J, CardenasRodriguez N, Huerta-Gertrudis B, Garcia-Cruz ME, Montesinos-Correa $H$, Sanchez-Gonzalez DJ, Camacho-Carranza R, Espinosa-Aguirre JJ. Acetonic and Methanolic Extracts of Heterotheca inuloides, and Quercetin, Decrease CCl(4)-Oxidative Stress in Several Rat Tissues. Evid Based Complemet Alternat Med : eCAM 2013; 2013: 659165.

8. Moretti E, Mazzi L, Terzuoli G, Bonechi C, lacoponi F, Martini S, Rossi C,Collodel G. Effect of quercetin,

Trop J Pharm Res, September 2014; 13(9): 1564 
rutin, naringenin and epicatechin on lipid peroxidation induced in human sperm. Reprod Toxicol 2012; 34: 651-657.

9. Maciel RM, Costa MM, Martins DB, Franca RT, Schmatz R, Graca DL, Duarte MM, Danesi CC, Mazzanti CM, Schetinger MR, Paim FC, Palma HE, Abdala FH, Stefanello N, Zimpel CK, Felin DV,Lopes ST. Antioxidant and anti-inflammatory effects of quercetin in functional and morphological alterations in streptozotocin-induced diabetic rats. Res Vet Sci 2013; 95: 389-397.

10. Tátraaljai D, Földes E, Pukánszky B. Efficient melt stabilization of polyethylene with quercetin, a flavonoid type natural antioxidant. Polymer Degradation and Stability 2014; 102: 41-48

11. Ravichandran $R$, Rajendran $M$, Devapiriam $D$. Antioxidant study of quercetin and their metal complex and determination of stability constant by spectrophotometry method. Food Chem 2014; 146 . 472-478

12. Joseph $D$, Muralidhara KM. Enhanced neuroprotective effect of fish oil in combination with quercetin against 3-nitropropionic acid induced oxidative stress in rat brain. Prog. Neuro-Psychopharmacol. Biol Psychiatry 2013; 40: 83-92.

13. Choi GN, Kim JH, Kwak JH, Jeong C-H, Jeong HR, Lee $U, H e o$ HJ. Effect of quercetin on learning and memory performance in ICR mice under neurotoxic trimethyltin exposure. Food Chem 2012; 132: 10191024.

14. Haleagrahara N, Siew CJ, Ponnusamy K. Effect of quercetin and desferrioxamine on 6hydroxydopamine (6-OHDA) induced neurotoxicity in striatum of rats. J Toxicol Sci 2013; 38: 25-33.

15. Jazvinscak JM, Cipak GA, Vukovic L, Vlainic J, Zarkovic N,Orsolic N. Quercetin supplementation: insight into the potentially harmful outcomes of neurodegenerative prevention. N-S Arch Pharmacol 2012; 385: 1185-1197.

16. Coelho-Dos-Reis JG, Gomes OA, Bortolini DE, Martins ML, Almeida MR, Martins CS, Carvalho LD, Souza JG, Vilela JM, Andrade MS,Barbosa-Stancioli EF. Evaluation of the effects of Quercetin and Kaempherol on the surface of MT-2 cells visualized by atomic force microscopy. J Virol Methods 2011; 174: 47-52.

17. Johari J, Kianmehr A, Mustafa M, Abubakar S,Zandi K. Antiviral Activity of Baicalein and Quercetin against the Japanese Encephalitis Virus. Int J Mol Sci 2012; 13: $16785-16795$.

18. Zandi K, Teoh BT, Sam SS, Wong PF, Mustafa MR,Abubakar S. Antiviral activity of four types of bioflavonoid against dengue virus type-2. Virol $J$ 2011; 8: 560.

19. Ramadan MF,Selim AMM. Antimicrobial and antiviral impact of novel quercetin-enriched lecithin. J Food Biochem 2009; 33: 557-571.
20. Bachmetov L, Gal-Tanamy M, Shapira A, Vorobeychik M, Giterman-Galam $T$, Sathiyamoorthy $P$, GolanGoldhirsh A, Benhar I, Tur-Kaspa R,Zemel R. Suppression of hepatitis $C$ virus by the flavonoid quercetin is mediated by inhibition of NS3 protease activity. J Viral Hepatitis 2012; 19: e81-88.

21. Fan D, Zhou X, Zhao C, Chen H, Zhao Y,Gong X. Antiinflammatory, antiviral and quantitative study of quercetin-3-O-beta-D-glucuronide in Polygonum perfoliatum L. Fitoterapia 2011; 82: 805-810.

22. Song JH, Shim JK,Choi HJ. Quercetin 7-rhamnoside reduces porcine epidemic diarrhea virus replication via independent pathway of viral induced reactive oxygen species. Virol $J$ 2011; 8: 460 doi: $10.1186 / 1743-422 X-8-460$

23. Baghel SS, Shrivastava N, Baghel RS, Agrawal P, Rajput $S$. A review of quercetin: antioxidant and anticancer properties, World J Pharm Pharm Sci 2012; 1(1): 146-160.

24. Gibellini L, Pinti M, Nasi M, Montagna JP, De Biasi S, Roat E, Bertoncelli L, Cooper EL,Cossarizza A. Quercetin and cancer chemoprevention. Evid Based Complement Alternat Med eCAM 2011; 2011: 591356.

25. Du G, Lin H, Yang Y, Zhang S, Wu X, Wang M, Ji L, Lu L, Yu L,Han G. Dietary quercetin combining intratumoral doxorubicin injection synergistically induces rejection of established breast cancer in mice. Int Immunopharmacol 2010; 10: 819-826.

26. Oh SJ, Kim O, Lee JS, Kim JA, Kim MR, Choi HS, Shim $J H$, Kang KW,Kim YC. Inhibition of angiogenesis by quercetin in tamoxifen-resistant breast cancer cells. Food Chem Ttoxicol 2010; 48: 3227-3234.

27. Russo M, Spagnuolo C, Tedesco I, Bilotto S, Russo GL. The flavonoid quercetin in disease prevention and therapy: facts and fancies. Biochem Pharmacol 2012; 83: 6-15.

28. Larson AJ, Symons JD, Jalili T. Therapeutic potential of quercetin to decrease blood pressure: review of efficacy and mechanisms. Adv Nutr 2012; 3: 39-46.

29. Kleemann R, Verschuren L, Morrison M, Zadelaar S, Van Erk MJ, Wielinga PY,Kooistra T. Anti-inflammatory, anti-proliferative and anti-atherosclerotic effects of quercetin in human in vitro and in vivo models. Atherosclerosis 2011; 218: 44-52.

30. Wang L, Wang B, Li H, Lu H, Qiu F, Xiong L, Xu Y, Wang $G$, Liu $X, W u H$, Jing $H$. Quercetin, a flavonoid with anti-inflammatory activity, suppresses the development of abdominal aortic aneurysms in mice. Eur J Pharmacol 2012; 690: 133-141.

31. Andres S, Tejido ML, Bodas R, Moran L, Prieto N, Blanco $C$, Giraldez FJ. Quercetin dietary supplementation of fattening lambs at $0.2 \%$ rate reduces discolouration and microbial growth in meat during refrigerated storage. Meat Sci 2013; 93: 207-212.

32. Božič M, Gorgieva S, Kokol V. Homogeneous and heterogeneous methods for laccase-mediated 
functionalization of chitosan by tannic acid and quercetin. Carbohydr Polym 2012; 89: 854-864.

33. Wu D, Kong Y, Han C, Chen J, Hu L, Jiang H, Shen X. DAlanine:D-alanine ligase as a new target for the flavonoids quercetin and apigenin. Int $\mathrm{J}$ Antimicrob Agents 2008; 32: 421-426.

34. De Souza KC, Bassani VL, Schapoval EE. Influence of excipients and technological process on antiinflammatory activity of quercetin and Achyrocline satureioides (Lam.) D.C. extracts by oral route. Phytomedicine : Int J Phytotherapy Phytopharmacol 2007; 14: 102-108.

35. Lin CF, Leu YL, Al-Suwayeh SA, Ku MC, Hwang TL, Fang JY. Anti-inflammatory activity and percutaneous absorption of quercetin and its polymethoxylated compound and glycosides: the relationships to chemical structures. Eur J Pharm Sci 2012; 47: 857864.

36. Garcia-Mediavilla V, Crespo I, Collado PS, Esteller A, Sanchez-Campos S, Tunon MJ, Gonzalez-Gallego J. The anti-inflammatory flavones quercetin and kaempferol cause inhibition of inducible nitric oxide synthase, cyclooxygenase-2 and reactive C-protein, and down-regulation of the nuclear factor kappaB pathway in Chang Liver cells. Eur J Pharmacol 2007; 557: 221-229.

37. Boesch-Saadatmandi $C$, Loboda A, Wagner $A E$, Stachurska A, Jozkowicz A, Dulak J, Doring $F$, Wolffram $S$, Rimbach $G$. Effect of quercetin and its metabolites isorhamnetin and quercetin-3glucuronide on inflammatory gene expression: role of miR-155. J Nutr Biochem 2011; 22: 293-299.

38. Anhe GF, Okamoto MM, Kinote A, Sollon C, Lellis-Santos C, Anhe FF, Lima GA, Hirabara SM, Velloso LA, Bordin S, Machado UF. Quercetin decreases inflammatory response and increases insulin action in skeletal muscle of ob/ob mice and in $L 6$ myotubes. Eur J Pharmacol 2012; 689: 285-293.

39. Boots AW, Wilms LC, Swennen EL, Kleinjans JC, Bast $A$, Haenen GR. In vitro and ex vivo anti-inflammatory activity of quercetin in healthy volunteers. Nutrition 2008; 24: 703-710.

40. Ying $H Z$, Liu YH, Yu B, Wang $Z Y$, Zang JN, Yu CH. Dietary quercetin ameliorates nonalcoholic steatohepatitis induced by a high-fat diet in gerbils. Food Chem Toxicol 2013; 52: 53-60.

41. Lekic N, Canova NK, Horinek A, Farghali $H$. The involvement of heme oxygenase 1 but not nitric oxide synthase 2 in a hepatoprotective action of quercetin in lipopolysaccharide-induced hepatotoxicity of $D$ galactosamine sensitized rats. Fitoterapia 2013; 87: 20-26.

42. Liu S, Hou W, Yao P, Li N, Zhang B, Hao L, Nussler AK, Liu L. Heme oxygenase-1 mediates the protective role of quercetin against ethanol-induced rat hepatocytes oxidative damage. Toxicol in Vitro 2012; 26: $74-80$

43. Mi Y, Zhang C, Li CM, Taneda S, Watanabe G, Suzuki $A K$, Taya K. Protective effect of quercetin on the reproductive toxicity of 4-nitrophenol in diesel exhaust particles on male embryonic chickens. J Reprod Develop 2010; 56: 195-199.

44. Farombi EO, Ekor M, Adedara IA, Tonwe KE, Ojujoh TO,Oyeyemi MO. Quercetin protects against testicular toxicity induced by chronic administration of therapeutic dose of quinine sulfate in rats. $J$ Basic Clinical Physiology Pharmacol 2012; 23: 39-44.

45. Sergent $T$, Vanderstraeten $J$, Winand $J$, Beguin $P$, Schneider Y-J. Phenolic compounds and plant extracts as potential natural anti-obesity substances. Food Chem 2012; 135: 68-73. 